\title{
The Relationship between Self-Confidence, Self-Efficacy, Grit, Usefulness, and Ease of Use of eLearning Platforms in Corporate Training during the COVID-19 Pandemic
}

\author{
Adriana Malureanu ${ }^{1,+}$, Georgeta Panisoara ${ }^{2, *,+}$ (D) and Iulia Lazar $3, *,+$ \\ 1 Doctoral School, Faculty of Psychology and Educational Science, Bucharest University, \\ 050663 Bucuresti, Romania; adriana-ioana.fechete@drd.unibuc.ro \\ 2 Psychology Department, Faculty of Psychology and Educational Science, Bucharest University, \\ 050663 București, Romania \\ 3 Teacher Training Department, Faculty of Psychology and Educational Science, Bucharest University, \\ 050663 București, Romania \\ * Correspondence: georgeta.panisoara@fpse.unibuc.ro (G.P.); iulia.lazar@fpse.unibuc.ro (I.L.) \\ + All authors contributed equally to the work.
}

Citation: Malureanu, A.; Panisoara, G.; Lazar, I. The Relationship between Self-Confidence, Self-Efficacy, Grit, Usefulness, and Ease of Use of eLearning Platforms in Corporate Training during the COVID-19 Pandemic. Sustainability 2021, 13, 6633. https://doi.org/10.3390/ su13126633

Academic Editors: Gabriela Topa,

Xuesong Zhai and Juan

Carlos Pérez-González

Received: 24 May 2021

Accepted: 6 June 2021

Published: 10 June 2021

Publisher's Note: MDPI stays neutral with regard to jurisdictional claims in published maps and institutional affiliations.

Copyright: (c) 2021 by the authors. Licensee MDPI, Basel, Switzerland. This article is an open access article distributed under the terms and conditions of the Creative Commons Attribution (CC BY) license (https:// creativecommons.org/licenses/by/ $4.0 /)$.

\begin{abstract}
This exploratory study contributes to the understanding of self-confidence as a predictor of self-efficacy, ease of use, and usefulness of eLearning platforms in corporate training. The present research explored the relationship among the employees' beliefs regarding self-confidence, grit, ease of use, self-efficacy, and usefulness of eLearning platforms in their workplace during the COVID19 pandemic. In total, 307 responses from Romanian employees who used eLearning platforms in corporate training (females $=60.3 \%$, males $=39.7 \%$, age range of less than 24 years $(12.1 \%)$ to over 55 years $(6.2 \%)$ ) were exploited for research. Data were analyzed through a path analysis model. Results indicate that grit (i.e., consistency of interest), self-efficacy, and perceived ease of use of eLearning platforms were considerably directly influenced by the self-confidence variable. Usefulness was directly influenced by the ease of use and was indirectly influenced by self-confidence. Mediation analysis indicated that full mediation occurs only through the ease of use of eLearning platforms variable in the relationship between self-confidence and usefulness. A unit increase in self-confidence will increase the expected value of grit by 0.54 units $(t=8.39, p<0.001)$, will indirectly increase the expected value of usefulness through ease of use by 0.15 units $(t=2.39, p=0.017)$, and will increase the expected value of self-efficacy by 0.53 units $(t=6.26, p<0.001)$. In addition, perceived ease of use of eLearning platforms in corporate training fully mediated the relationship of usefulness regressed on self-confidence $(\beta=0.20, t=2.51, p=0.012)$. These novel results reveal the contributions of self-confidence, consistency of interest as a grit dimension, and ease of use of eLearning platforms in predicting lifelong learning solutions, which improve business outcomes. The related investigation and consequences were further considered.
\end{abstract}

Keywords: corporate training; COVID-19 pandemic; ease of use; eLearning platforms; grit; selfconfidence; self-efficacy; usefulness

\section{Introduction}

Online learning has shown significant growth in new settings imposed by the COVID19 pandemic [1] that has influenced the way of life in general and learning in particular [2,3] Both online work and eTraining have become a target in the context of pandemics and the conditions of physical distancing, but the advantages of this mode of work and instruction will remain after the pandemic has passed. In addition, personalized online training using innovative eLearning platforms is a better solution to educate heterogeneous employees [4]. For this approach, a cloud learning management system (LMS) platform is required [5]. However, organizational and individual factors lead to the adoption or not of new technologies among employees in companies. 
Occupational safety and health ( $\mathrm{OSH})$ education has recently been using eLearningbased programs to increase learners' work motivation [6]. Consequently, increasingly companies and entrepreneurs are adopting online training, using learning platforms [7]. Traditional determinants that justified the corporate training (e.g., a better-skilled workforce or a larger organization size) are unhelpful when explaining why a corporate used eLearning for employee training purposes [8]. If an employee believes that he or she is competent in managing his or her work responsibilities and completing important tasks, business outcomes will be improved. A detailed explanation of the functionalities of an eLearning platform is well appreciated.

In this context, multiple non-cognitive factors in the educational field, such as selfconfidence, grit, and self-efficacy, can shape the desired learning outcomes [9]. In addition, cognitive factors such as ease of use are a strong facilitator of perceived usefulness of digital tools $[10,11]$. Literature has provided ample data that confirm the associations between self-confidence, grit, and self-efficacy $[9,12,13]$ but also between ease of use and usefulness as key predictors of digital educational tool adoption [14]. However, the non-cognitive and cognitive factors that simultaneously influence the eLearning efficiency and perceived usefulness are not deeply investigated. These conclusions represent gaps in the literature. Therefore, the diversity in the conceptualization of lifelong learning solutions for business needs to be reduced in future studies.

In this research, it was explored how the adult population, involved in work, reacts during the pandemic to e-learning, to training courses within companies, or those available in the form of various educational resources. The main study aim was to analyze how numerous non-cognitive factors-self-confidence, self-efficacy, and grit-interact and influence directly or indirectly the degree of adoption of eLearning in companies, namely, the degree of interest, pleasure of use, and consideration of the usefulness of eLearning learning modules. Understanding the factors associated with lifelong learning strategies allows the development of ways to minimize the gap between personal needs and business performance.

Based on the literature review brief described above, this research tested the links among self-confidence, self-efficacy, grit, usefulness, and ease of use of eLearning platforms in corporate training during the COVID-19 pandemic. The understanding of the efficiency of eLearning platform uses by employees will be improved. Briefly, this study explored how self-confidence is connected directly or indirectly to self-efficacy across employees who regularly participated in corporate training using digital tools. Hence, corporate training based on eLearning platforms is an interesting and necessary research domain. Based on the aims of the study and literature gaps, the following research questions were expressed:

Research Question 1 (RQ1): What factors significantly influence self-efficacy and perceived usefulness of employees to use eLearning platforms in corporate training during the COVID-19 pandemic?

Research Question 2 (RQ2): Does the grit significantly moderate the relationship between perceived self-confidence and self-efficacy related to eLearning platform usage by employees in corporate training?

Research Question 3 (RQ3): Does the ease of use significantly moderate the relationship between perceived self-confidence and usefulness of eLearning platform usage by employees in corporate training?

The research conceptual model is presented in Figure 1. 


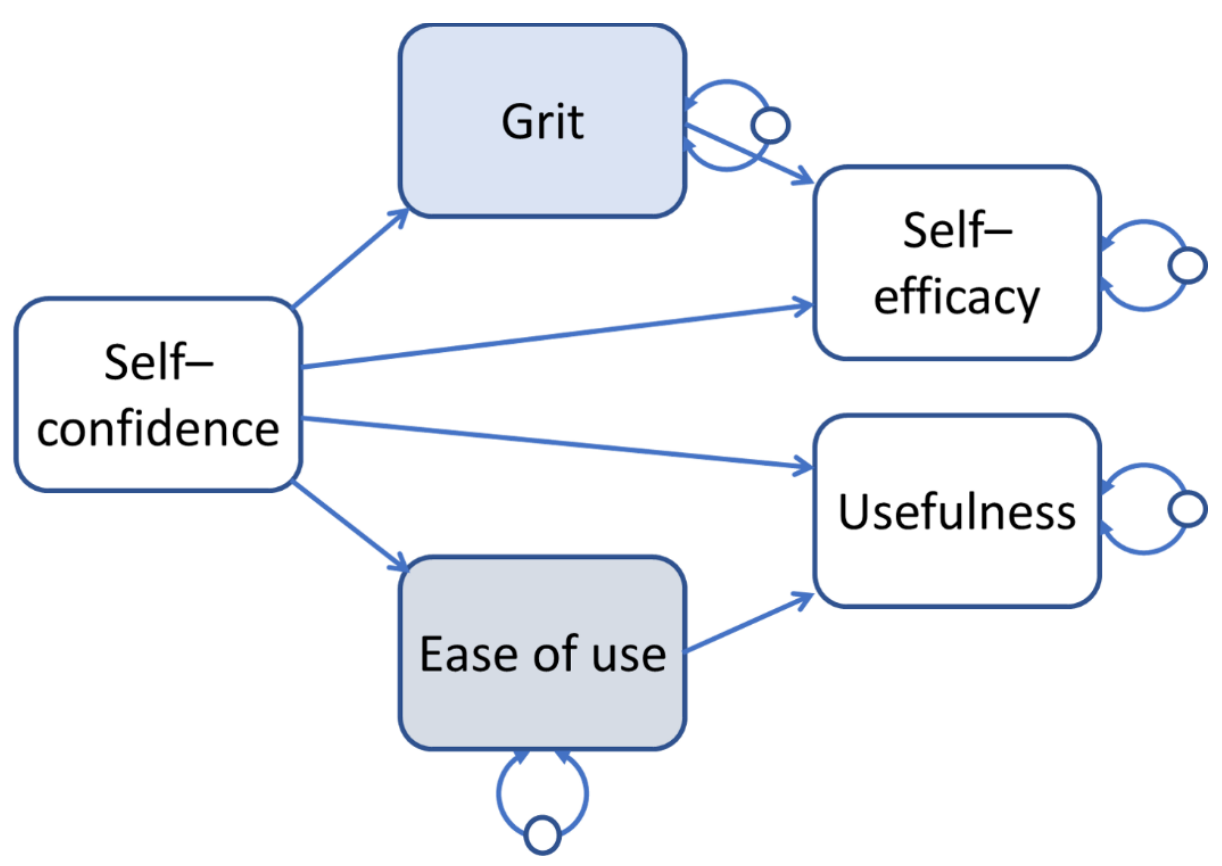

Figure 1. Research conceptual model. Mediators' variables are marked with blue.

\subsection{Theoretical Background}

\subsubsection{Self-Confidence}

Self-confidence implies a person's professed capability to tackle situations effectively on his own without leaning on others and to have constructive self-evaluation; self-confidence is an optimistic look at one's own self [15]. Bandura's [16] social learning theory posits motivation, reinforcement, and past experience as key components to promote confidence [17].

A domain analysis of the term [18] indicates that in business, overarching uses refer to self-confidence concerning an essential part of the skill set for effective leadership [18]. The educational arena uses self-confidence in the realm of academic success or failure $[19,20]$. Psychological literature uses psychological trait comprehension [21,22] and male-versusfemale confidence $[23,24]$.

Confidence in itself develops from childhood. Accumulation of inter- and intrapersonal experiences defines the self-confidence concept [25]; it derives from several factors stemming from personal experience [26]. Thus, success increases self-confidence, while failure has the opposite effect. The second factor influencing self-confidence is the social messages received from those around us (community, family, school, colleagues). Exposure to negative messages diminishes self-confidence [27]. As regards oral communication, confidence in itself is of major importance [26]. However, the lack of self-confidence leads to a lack of interest and in turn to a lower effort on behalf of students.

Dörnyei [28] considered the concept of self-confidence closely related to self-esteem. The two concepts reflect the perception of an individual's own abilities, which leads to the concept of self-efficacy. Pierce et al. [27] defined self-confidence as the degree to which an individual believes him/herself to be capable, significant, and worthy.

Another factor that plays an important role in learning and efficiency in an organization is the self-confidence of the leader. A leader confident in his own power empowers the organization and motivates it [29]. The study assumes that self-sacrifice and self-confidence interact, such that the effects of self-sacrifice on collective identification are stronger when self-confidence is high rather than lower. The authors conclude that the expectation of success communicated by a self-confident leader may not only increase the identification of the employees with the organization but also increase the follower's self-efficacy and the collective efficacy. 
A study on eLearning [30] notes among its conclusions that successfully completing online or computer-based courses builds self-knowledge and self-confidence and encourages students to take responsibility for their learning. Clark [31] came to a similar conclusion, saying that a major benefit of learning technology is that it can be motivating. eLearning can motivate, develop confidence and self-esteem, overcome many barriers faced by students, personalize learning experience, broaden access, and improve learning experience, while helping people develop their ICT skills [31].

\subsubsection{Self-Efficacy}

Bandura [16] defined self-efficacy as someone's beliefs "about their capabilities to produce designated levels of performance that exercise influence over events that affect their lives" (p. 71). The term refers to "someone beliefs in their capabilities to organize and execute the courses of action required to produce given attainments" [16] (p. 3). Therefore, self-efficacy refers to one's perception of the ability to perform a task or engage in an activity [32]. Believing in yourself is the human characteristic of believing in one's own abilities to perform a task or to cope in a certain situation but especially in novel or difficult tasks, and it is a concept closely related to motivation [33]. Self-efficacy is associated with feelings of confidence in one's own ability and can be very closely related to the curiosity to learn more or the desire to engage in tasks seen as challenges, rather than in tasks of general interest.

Self-efficacy is the belief of a person in his ability to succeed. People who perceive themselves as efficient attribute success to personal effort, while those with a low level of efficiency attribute it to external factors. People with a high level of efficiency attribute possible failures to insufficient personal effort, while those who consider themselves ineffective attribute the failure to their low abilities and capacities [34].

The concept of Bandura can be interpreted as "I believe I can" [16,34]. Belief in their own capabilities leads people to perceive tasks with more courage, having the ability to overcome them much more easily. This concept leads to a minimization of stress and a reduction in the risk of anxiety [34]. Studies show that education has a positive significant influence on self-efficacy, the same as a role model has a positive significant influence on self-efficacy [35]. Self-efficacy is associated with work-related performance, learning and achievement, and adaptability to new technology [36].

Research on self-efficacy started long before the emergence of e-learning. Concern for this topic arose between the 1970s and 1990s, while studies on self-efficacy in online learning have progressed since 2008 [37,38]. Hodges [38] says that "research on self-efficacy in online environments is in its infancy" (p. 10), thus marking the start of research in this area.

Alqurashi [37] analyzed the specialized literature in the field of self-efficacy in online learning, considering the studies in the field performed between 1997 and 2015 . He cataloged the studies conducted according to the pursued factor, for example, studies on the technical factor, such as computer self-efficacy, internet self-efficacy, informationseeking self-efficacy, and learning management system (LMS) self-efficacy. Other studies analyzed focused on the learning factor [39-45]. Research on self-efficacy in general in online learning environments has also been analyzed [46].

A literature review of the relationship between self-efficacy and online learning suggests that there are two opposing possible hypotheses [37]. A possible hypothesis is that self-efficacy plays an important role in online learning; another possible hypothesis is that self-efficacy does not play an important role in online learning.

In a systematic review based on research between 2005 and 2017, Peechapol et al. [47] showed the factors that can influence self-efficacy in the online learning environment. The result of Bates and Khasawneh [48] shows that previous online learning, instructoracquired skill, instructor feedback, and eLearning system anxiety influenced students' self-efficacy in the context of online learning. 
These factors are consistent with the sources of self-efficacy introduced by Bandura [16], who stated that self-efficacy expectations are based on four major sources of information: enactive mastery experience, vicarious experience, verbal persuasion, and physiological and affective states [47]. Self-efficacy is the key to success in all activities, including online learning.

\subsubsection{Grit}

As defined in the literature, grit contains two basic elements for long-term goals: perseverance and passion (deep knowledge of what you want) [49]. Perseverance, consistency, and maintaining interest for a long time are traits that, along with endurance, ambition, conscientiousness, awareness, and self-control, outline the grit-type personality [49]. It is about moving in a direction with consistency and having a compass that guides your decisions. As recent research indicates, grit entails resolution, fortitude, resilience, perseverance, tenacity, and stamina [50]. The grit concept, as a characteristic of an individual to pursue a long-term objective, is closely related to intrinsic motivation. Grit, defined as passion and persistence in pursuing long-term goals, is an important factor related to student engagement and academic success [49,51]. It is thus assumed that the chances of overcoming possible obstacles and achieving good results are on the side of those who not only make more effort but also love what they do [51]. Studies reveal that grit is highly related to age and educational level $[49,51]$. In the field of education, grit has been shown to be a reliable predictor of better learning outcomes.

In the vision of Duckworth [52], talent matters, but it is not paramount-what counts twice as much is effort, which has a much greater impact on achievement than talent. To maintain motivation, it is necessary to combine daily goals with greater vision and longterm plans. A study conducted in Finnish schools [53] indicated that the grit-perseverance of effort had a small but unique effect on young adults' academic achievement. The study comes with two relevant implications. First, contrary to the much-discussed assumption [52], a growth mindset only acts as a marginal predictor of grit, at least for adolescent groups. Second, encouraging adolescents to set a goal and to commit to this goal helps develop their grit. Thus, the findings of the study indicate a poor association between the growth mindset and grit [53].

Grit as a determining factor of the success of eLearning systems has been studied in research on university students [50]. The researchers concluded that grit has positive effects on satisfaction and on students' individual performance. The results help improve eLearning strategies and to understand eLearning success, explained by students' skills and system characteristics. The grit for completing eLearning courses is defined as the amount of time in completing the courses, the frequency with which one wishes to complete such courses persisting despite obstacles. Conscientious people invest in behaviors that can improve their future [54], also shown in a study on the influence of grit on lifestyle in pandemics [55].

\subsubsection{TAM Model. Ease of Use and Usefulness of eLearning Platforms}

Technology acceptance model (TAM) [56] predicts the intention to use technology and is founded on the theory of planned behavior, which points out as a central factor the individual's intention to perform a behavior. To capture motivational factors, the intentions are defined. They are indicators of how willing people are to try and how much effort they intend to put in, to do, or perform a behavior [57].

TAM includes several variables, such as perceived utility, perceived ease of use, and attitude toward technology, with which they directly or indirectly explain behavioral intentions regarding the use of technology. The model has been extended with external variables such as self-efficacy, subjective rules, and facilitating conditions of use of technology [58]. 
As a general rule established by the theory of planned behavior, the stronger the intention to engage in a behavior, the greater the likelihood that that behavior will be performed. Certain behaviors also largely depend on external factors, such as the availability of opportunities and resources needed (time, money, skills, cooperation with others) [57]. A conclusion of the model is that if there is both the intention of the person and the necessary resources and opportunities, the behavior should enjoy success.

TAM is successfully used for educational research. A bibliographic study with technology acceptance theory and education as key terms in scholarly articles published in the ScienceDirect Freedom Collection, Elsevier, and Wiley Journals between 2015 and 2020 revealed a total of 18,778 journal articles examining these topics and the link between them.

A conclusion of a recent study, which measured the adoption of technology by educators and trainers [58], was that at least two global trends can be observed:

o Inclusion of digital skills in education systems;

o Encouraging teaching factors to include technology.

A study published in 2020 [59] analyzed from the perspective of the TAM the importance of digital video resources in education when practical activities are involved. In the case of video-type resources, there is the possibility of returning to a sequence or making simulations of imaginary cases based on real cases. Therefore, the adoption of digital resources is preferable.

\subsection{Research Hypotheses}

Based on the literature review, the following hypotheses were proposed:

Hypothesis 1 (H1). Perceived self-confidence has a significant direct effect on grit related to eLearning platform usage in corporate training during the COVID-19 pandemic.

Hypothesis 2 (H2). Perceived self-confidence has a significant direct effect on perceived self-efficacy of eLearning platform usage in corporate training during the COVID-19 pandemic.

Hypothesis 3 (H3). Perceived self-confidence has a significant direct effect on perceived ease of use of eLearning platforms in corporate training during the COVID-19 pandemic.

Hypothesis 4 (H4). Perceived self-confidence has a significant direct effect on perceived usefulness of eLearning platform usage in corporate training during the COVID-19 pandemic.

Hypothesis 5 (H5). Grit has a significant direct effect on perceived self-efficacy of eLearning platform usage in corporate training during the COVID-19 pandemic.

Hypothesis 6 (H6). Perceived ease of use has a significant direct effect on the usefulness of eLearning platform usage in corporate training during the COVID-19 pandemic.

Hypothesis 7 (H7). Grit mediated the relationship between perceived self-confidence and selfefficacy of eLearning platform usage in corporate training during the COVID-19 pandemic.

Hypothesis 8 (H8). Ease of use mediated the relationship between perceived self-confidence and usefulness of eLearning platform usage in corporate training during the COVID-19 pandemic.

Note: "a" represent positive Hypothesis.

\section{Materials and Methods}

\subsection{Participants}

Research data were acquired as part of a larger investigation during the COVID-19 pandemic on the behavior of Romanian employees toward eLearning in corporate training. This larger study, approved by the Commission of Ethics and Academic Professional 
Deontology of the University of Bucharest (UB), is ongoing. The current study (September 2020-March 2021) exploited only a part of a larger research, which is ongoing. The target population was employees living in Romania and working within companies that frequently organized eLearning training courses on different topics of interest to them. Through a snowball method, via Facebook and emails to collaborators, participants were recruited. All research participants confirmed that they consented to take part in this study. Information about gender, work seniority, job seniority, age, education, interval training (e.g., every week, every month, etc.), and beliefs regarding the necessity of a virtual instructor was obtained. Of the 400 people who started the survey, 93 were excluded due to missing data points. Therefore, a total of $n=307$ was used for the current research. Table 1 presents the sample sociodemographic data. Dataset to explore the relationship between self-confidence, self-efficacy, grit, usefulness, and ease of use of eLearning platforms in corporate training during the COVID-19 pandemic in Romania is available in Supplementary Material Table S1.

Table 1. Respondents' particular sociodemographic, career, academic qualification, and key beliefs regarding the necessary period for continuous training and necessity of the presence of a virtual instructor.

\begin{tabular}{|c|c|c|}
\hline Item & Overall & Frequency $(\%)$ \\
\hline Total number $\mathbf{n}$ & 307 & 100 \\
\hline \multicolumn{3}{|l|}{ Gender } \\
\hline Female & 185 & 60.3 \\
\hline Male & 122 & 39.7 \\
\hline \multicolumn{3}{|l|}{ Age } \\
\hline under 24 years & 37 & 12.1 \\
\hline between 24 and 35 years & 138 & 45.0 \\
\hline between 36 and 45 years & 87 & 28.3 \\
\hline between 46 and 55 years & 26 & 8.5 \\
\hline after 55 years & 19 & 6.2 \\
\hline \multicolumn{3}{|l|}{ Work seniority } \\
\hline under 1 year & 11 & 3.6 \\
\hline between 1 and up to 3 years & 26 & 8.5 \\
\hline between 3 and up to 5 years & 48 & 15.6 \\
\hline between 5 and up to 10 years & 46 & 15.0 \\
\hline between 10 and up to 15 years & 65 & 21.2 \\
\hline between 15 and up to 20 years & 56 & 18.2 \\
\hline between 20 and up to 25 years & 22 & 7.2 \\
\hline more than 25 years & 33 & 10.7 \\
\hline \multicolumn{3}{|l|}{ Job seniority } \\
\hline under 1 year & 65 & 21.2 \\
\hline between 1 and up to 3 years & 90 & 29.3 \\
\hline between 3 and up to 5 years & 54 & 17.6 \\
\hline between 5 and up to 10 years & 29 & 9.4 \\
\hline between 10 and up to 15 years & 44 & 14.3 \\
\hline between 15 and up to 20 years & 15 & 4.9 \\
\hline between 20 and up to 25 years & 5 & 1.6 \\
\hline more than 25 years & 5 & 1.6 \\
\hline \multicolumn{3}{|l|}{ Education } \\
\hline higher school & 98 & 31.9 \\
\hline university & 135 & 44.0 \\
\hline post university & 74 & 24.1 \\
\hline
\end{tabular}


Table 1. Cont.

\begin{tabular}{lcc}
\hline Item & Overall & Frequency (\%) \\
\hline Interval training & 39 & \\
every week & 103 & 12.7 \\
every month & 83 & 33.6 \\
every trimester & 35 & 27.0 \\
every semester & 47 & 11.4 \\
every year & & 15.3 \\
\hline Virtual instructor & 206 & \\
Yes & 47 & 67.1 \\
I am not sure & 54 & 15.3 \\
No & & 17.6 \\
\hline
\end{tabular}

\subsection{Instruments}

The main aim of the survey was to focus on employees' perception of motivation factors and their intention to use eLearning platforms in corporate training. The survey referred to eTraining in a specific format of a learning management system (LMS) platform. Based on an extensive literature review, the items for each dimension were self-developed or adapted. The scales for self-confidence and self-efficacy are freely available in the Romanian version of the International Personality Item Pool (see http:/ / researchcentral.ro/repository, accessed on 2 November 2021). The Romanian translation of the self-confidence and selfefficacy scales was made by experts [60]. Voluntary research participants have right to withdraw from the study [61]. They assessed all items' scales for self-confidence (3 items, such as "Have a low opinion of myself") and self-efficacy (5 items, such as "Know how to get things done") on four-point Likert-type scales ranging from "strongly disagree" (1) to "strongly agree" (4). The grit scale items $[49,62]$ ( 3 items, such as "I have difficulty maintaining my focus on projects that take more than a few months to complete") were adapted from literature [60]. This scale is posted on a free online repository [60]. Research participants assessed all items' scales for grit on five-point Likert-type scales ranging from "It suits me very well" (1) to "It does not suit me at all" (5). The trend of the grit scale is reverse from the trend of the self-confidence scale. This aspect was considered in the result interpretation. The TAM items corresponding to the ease of use dimension ( 3 items, such as "I found easy to use online course through eLearning platform") and usefulness (5 items, such as "Online training improves my performance at work") were self-developed or adapted [63]. The scale used for the perception factor of the usefulness of online courses was pretested in research on 250 employees of a pharmaceutical company using an LMS learning platform. Respondents assessed all ease of use and usefulness scale items on seven-point Likert-type scales ranging from "strongly disagree" (1) to "strongly agree" (7).

\subsection{Procedure We}

Several approaches were used to validate the instruments. The correlation matrix determinant was computed [64] to evaluate multicollinearity [65]. First, the reliability of the analysis was examined based on the sample size [66] used for research. The participantto-item ratio for this analysis was approximately 30 to 1 , where the sample size was 307 and the number of variables included was 10; thus, the given sample size is sufficient to produce reliable results [67]. Jamovi 1.6.14, Intellectus Statistics, and Smart-PLS 3.0 were used as statistical software instruments for various evaluations. Descriptive analyses using Jamovi 1.6.14 and Intellectus Statistics were conducted to summarize responses. Smart-PLS 3.0 was used to analyze the measurement and structural models [68]. 
The partial least squares structural equation modeling (PSL-SEM) method [69] was used to test hypotheses and the research model. The reason for the PLS-SEM method usage is the prediction-oriented and exploratory nature of this research [69]. The PLS-SEM method was implemented in two steps (evaluating the fit of the measurement model and of the structural model), similar to other studies [70].

\subsubsection{Measurement Model (Outer Model) Evaluation}

The measurement model (outer model) was evaluated based on several criteria related to formative and reflective constructs $[68,69]$ :

(a) Evaluating the common method bias using Pearson's correlations to identify if there are correlations across items greater than 0.90 ;

(b) The variance inflation factor (VIF) for the indexes should be less than 3.3 to avoid the multicollinearity problem;

(c) All indexes have significant t-values;

(d) Individual item reliability (Cronbach's alpha) $>0.7$ to assure a good convergent validity;

(e) Composite reliability ( $\mathrm{CR}>0.7)$ to assure a good convergent validity;

(f) Factor loadings (outer loading) $>0.7$ to assure a good convergent validity; however, item loading between 0.5 and 0.7 should be retained as long as CR and AVE meet their required thresholds [69];

(g) Average variance extracted (AVE) $>0.5$ to assure a good convergent validity;

(h) Fornell-Larcker criterion: the correlations with other reflective dimensions should be less than the "square root" of AVE of the dimension to assure good discriminant validity;

(i) Cross-loading criterion: heterotrait-monotrait $(\mathrm{HTMT}<0.90)$ to assure good discriminant validity.

\subsubsection{Structural Model (Inner Model) Evaluation}

For analyzing the structural model, a minimum confidence level of $95 \%$ was considered. The structural model (inner model) was evaluated using the bootstrapping procedure with 307 cases (selecting the 1000 samples and no-sign-changes options) and based on the following steps:

(a) Measure the overall model fit using standardized root mean squared residual (SRMR) index;

(b) Test the significance of the path coefficients in the inner model using the two-tailed t-test;

(c) Test the significance of the outer model loadings using the t-test;

(d) Test the significance of the total all-path effects using the t-test;

(e) Test the significance of the mediation effects.

\section{Results}

\subsection{Descriptive Statistics}

The means, standard deviations, standard error, minimum, maximum, skewness, kurtosis, and Cronbach's $\alpha$ for each factor are presented in Table 2. The skewness is lower than 2 in absolute value, and thus all variables are considered symmetrical about its mean. The kurtosis is greater than 3 in only three cases and lower than 5 in all cases [65]. Therefore, after the normality of the research variables was scrutinized, all skewness and kurtosis values were found within an acceptable range. 
Table 2. Summary statistics of latent factors and their reliability (Cronbach's alpha).

\begin{tabular}{|c|c|c|c|c|c|c|c|c|c|c|}
\hline Factor & Variable & $\mathbf{M}$ & SD & $n$ & SE & Min & Max & Skewness & Kurtosis & Cronbach's Alpha \\
\hline \multirow{3}{*}{ Self-confidence } & SC6 & 1.65 & 0.62 & 341 & 0.03 & 1 & 4 & 0.56 & 0.13 & \multirow{3}{*}{0.73} \\
\hline & SC4 & 1.66 & 0.66 & 349 & 0.04 & 1 & 4 & 0.74 & 0.53 & \\
\hline & SC5 & 1.77 & 0.69 & 331 & 0.04 & 1 & 4 & 0.61 & 0.3 & \\
\hline \multirow{5}{*}{ Self-efficacy } & SE5 & 3.34 & 0.54 & 337 & 0.03 & 1 & 4 & -0.09 & -0.11 & \multirow{5}{*}{0.85} \\
\hline & SE4 & 3.3 & 0.48 & 330 & 0.03 & 2 & 4 & 0.55 & -0.9 & \\
\hline & SE11 & 3.32 & 0.58 & 329 & 0.03 & 1 & 4 & -0.47 & 0.93 & \\
\hline & SE12 & 3.28 & 0.56 & 327 & 0.03 & 2 & 4 & -0.02 & -0.51 & \\
\hline & SE14 & 3.3 & 0.54 & 323 & 0.03 & 1 & 4 & -0.04 & 0.11 & \\
\hline \multirow{3}{*}{ Grit } & GM3r & 2.13 & 0.91 & 342 & 0.05 & 1 & 5 & 0.71 & 0.38 & \multirow{3}{*}{0.84} \\
\hline & GM4r & 2.17 & 0.9 & 339 & 0.05 & 1 & 5 & 0.72 & 0.44 & \\
\hline & GM5r & 1.94 & 0.97 & 338 & 0.05 & 1 & 5 & 1.12 & 1.12 & \\
\hline \multirow{5}{*}{ Usefulness } & EE1 & 6.21 & 1.24 & 350 & 0.07 & 1 & 7 & -1.93 & 3.9 & \multirow{5}{*}{0.94} \\
\hline & EE3 & 5.87 & 1.41 & 354 & 0.07 & 1 & 7 & -1.4 & 1.7 & \\
\hline & EE2 & 6.05 & 1.31 & 358 & 0.07 & 1 & 7 & -1.64 & 2.71 & \\
\hline & EE5 & 6.03 & 1.37 & 342 & 0.07 & 1 & 7 & -1.64 & 2.37 & \\
\hline & EE8 & 5.95 & 1.33 & 340 & 0.07 & 1 & 7 & -1.41 & 1.61 & \\
\hline \multirow{3}{*}{ Ease of use } & EE11 & 6.14 & 1.21 & 340 & 0.07 & 1 & 7 & -1.78 & 3.67 & \multirow{3}{*}{0.76} \\
\hline & EE12 & 6.16 & 1.19 & 334 & 0.06 & 1 & 7 & -1.78 & 3.56 & \\
\hline & EE10 & 5.43 & 1.67 & 345 & 0.09 & 1 & 7 & -1.05 & 0.3 & \\
\hline
\end{tabular}

Note: Each legend item is presented in Supplementary Material Table S1.

\subsection{Results of the Measurement Model (Outer Model) Evaluation}

Before evaluation of the measurement model, tests for multicollinearity [71] were performed. The determinant value for the correlation matrix was 0.3108 , suggesting that there was no data multicollinearity [72]. Therefore, the absence of multicollinearity within the dataset was demonstrated. The common method bias using Pearson's correlations was used to identify if there are correlations across items greater than 0.90 (see Table 3). Most research variables were significantly correlated. Self-efficacy was negatively correlated with grit but positively correlated with self-confidence, ease of use, and usefulness.

Table 3. Correlations between latent variables.

\begin{tabular}{|c|c|c|c|c|c|c|}
\hline & Correlation Coefficient & Self-Confidence & Ease of Use & Grit & Usefulness & Self-Efficacy \\
\hline Self-confidence & Pearson's r & - & & & & \\
\hline Ease of use & $\begin{array}{c}\text { Pearson's r } \\
p \text {-value }\end{array}$ & $\begin{array}{c}0.11 \\
0.063^{n s}\end{array}$ & - & & & \\
\hline Grit & $\begin{array}{c}\text { Pearson's r } \\
p \text {-value }\end{array}$ & $\begin{array}{l}-0.40 \\
<0.001\end{array}$ & $\begin{array}{l}-0.06 \\
0.321\end{array}$ & - & & \\
\hline Usefulness & $\begin{array}{c}\text { Pearson's r } \\
p \text {-value }\end{array}$ & $\begin{array}{c}0.13 \\
0.020\end{array}$ & $\begin{array}{c}0.71 \\
<0.001\end{array}$ & $\begin{array}{c}-0.05 \\
0.375^{\mathrm{ns}}\end{array}$ & - & \\
\hline Self-efficacy & $\begin{array}{c}\text { Pearson's r } \\
p \text {-value }\end{array}$ & $\begin{array}{c}0.45 \\
<0.001\end{array}$ & $\begin{array}{c}0.12 \\
0.038\end{array}$ & $\begin{array}{l}-0.31 \\
<0.001\end{array}$ & $\begin{array}{c}0.16 \\
0.006\end{array}$ & - \\
\hline
\end{tabular}

Note. ns = non-significant.

The Cronbach's alpha value is greater than 0.70 (Table 2), which demonstrates that the measurement is reliable [73]. Then, convergent and discriminant validity were tested. The items with loadings $<0.50$ or cross-loadings were removed from analyses. Composite reliability was greater than the desirable value of 0.70 in all cases. The average variance extracted, reported in Table 4, was $>0.50$ for all factors, thereby fulfilling the conditions of Fornell and Larcker. 
Table 4. Convergent validity.

\begin{tabular}{ccc}
\hline Factor & Composite Reliability & Average Variance Extracted (AVE) \\
\hline Ease of use & 0.81 & 0.60 \\
Grit & 0.82 & 0.60 \\
Self-confidence & 0.74 & 0.50 \\
Self-efficacy & 0.85 & 0.53 \\
Usefulness & 0.94 & 0.74 \\
\hline
\end{tabular}

Therefore, the reliability and convergent validity requirements were met by the measurement model [74]. Variables' discriminant validity was evaluated using cross-loadings and Fornell and Larcker criterion [75] (Table 5). Table 5 shows that the square roots of the average variance extracted (AVE) [76] for the corresponding factors provide evidence of discriminant validity. SRMR was found to be 0.043 , which was less significant than the threshold of 0.08 , suggesting an excellent model fit. Therefore, all the indexes and constructs passed the measurement model evaluation procedures.

Table 5. Discriminant validity of the constructs using cross-loadings and Fornell and Larcker criterion.

\begin{tabular}{cccccc}
\hline Factor & Ease of Use & Grit & Self-Confidence & Self-Efficacy & Usefulness \\
\hline Ease of use & 0.77 & & & & \\
Grit & -0.12 & 0.77 & & & \\
Self-confidence & 0.18 & -0.54 & 0.70 & 0.73 & \\
Self-efficacy & 0.18 & -0.41 & 0.60 & 0.21 & 0.86 \\
Usefulness & 0.82 & -0.07 & 0.20 & \\
\hline
\end{tabular}

\subsection{Results of the Structural Model (Inner Model) Evaluation}

The direct regressions were examined based on an alpha value of 0.05 (Figure 2).

Self-confidence significantly predicted grit, $\mathrm{B}=-0.54, \mathrm{t}=-8.39, p<0.001$, indicating that a one-unit increase in self-confidence will increase the expected value of grit by 0.54 units, and thus H1a was supported. The self-confidence scale (i.e., "strongly disagree" (1) to "strongly agree" (4)) has a reverse trend, unlike the grit scale (i.e., "It suits me very well" (1) to "It does not suit me at all" (5)). Self-confidence significantly predicted self-efficacy, $\mathrm{B}=0.53, \mathrm{t}=6.26, p<0.001$, indicating that a one-unit increase in self-confidence will increase the expected value of self-efficacy by 0.53 units, and thus $\mathrm{H} 2 \mathrm{a}$ was supported. Self-confidence significantly predicted ease of use, $\mathrm{B}=0.18, \mathrm{t}=2.37, p=0.018$, indicating that a one-unit increase in self-confidence will increase the expected value of ease of use by 0.18 units, and thus H3a was supported. Self-confidence did not directly significantly predict usefulness, $\mathrm{B}=0.06, \mathrm{t}=1.02, p=0.307$, suggesting that there is no direct relationship between self-confidence and usefulness. Therefore, H4a was not confirmed. Grit has no effect on self-efficacy, $\mathrm{B}=-0.11, \mathrm{t}=-1.43, p=0.152$, indicating that H5a was not supported. Ease of use significantly predicted usefulness, $\mathrm{B}=0.80, \mathrm{t}=17.81, p<0.001$, indicating that a one-unit increase in ease of use will increase the expected value of usefulness by 0.80 units, and thus H6a was supported. 


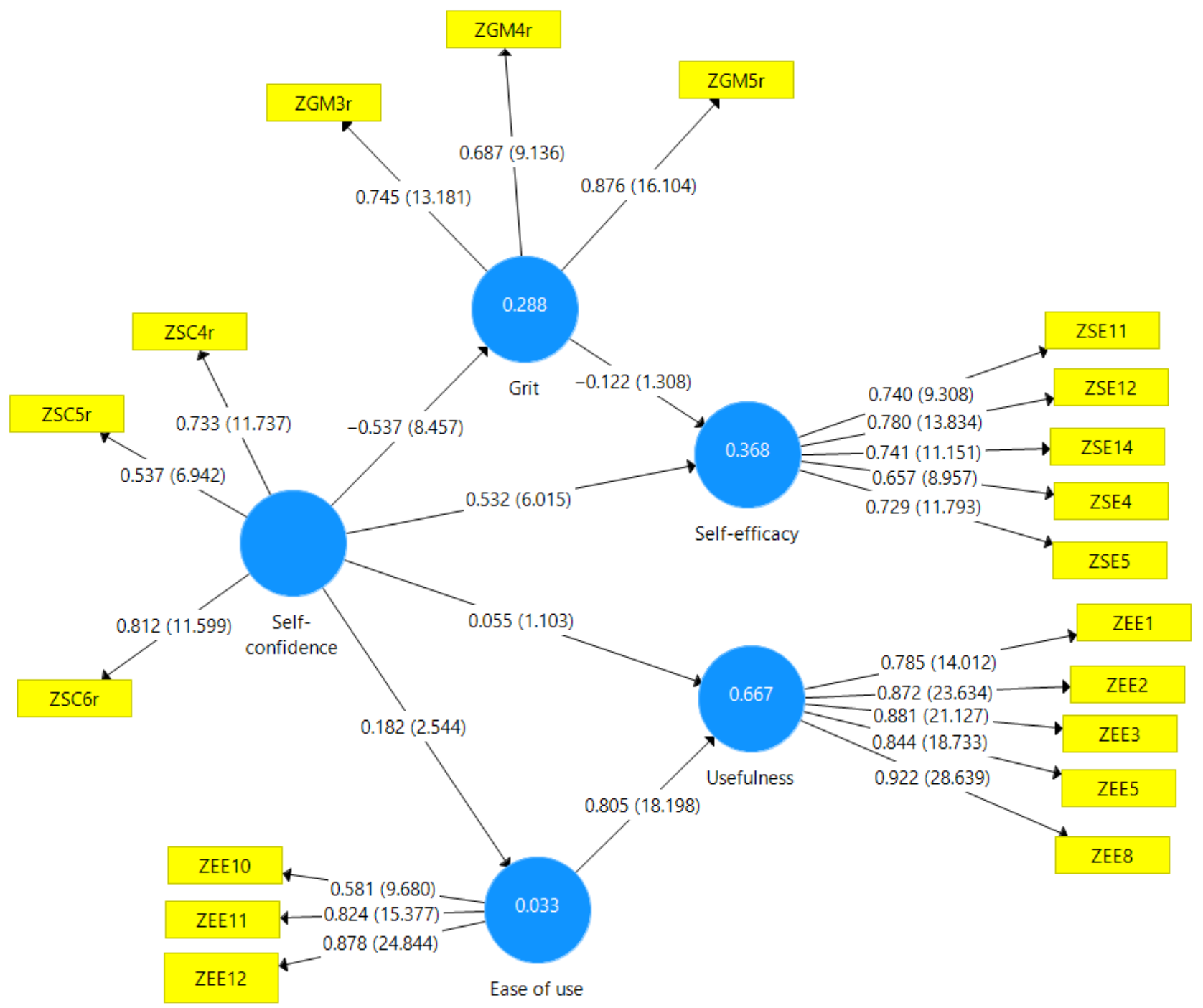

Figure 2. The structural equation model of the direct effect of self-confidence on other variables and mediating effect of grit and ease of use. The relationship is significant if the $t$ value is above 1.96 [77]. Path coefficients and $t$-values are presented.

\subsection{Mediation Model Results}

Hypothesis 7 suggested that grit mediated the relationship between perceived selfconfidence and self-efficacy of eLearning platform usage in corporate training. Hypothesis 8 suggested that ease of use mediated the relationship between perceived self-confidence and usefulness of eLearning platform usage in corporate training. Smart-PLS 3.0 was used to conduct a mediation model testing for each hypothesis (e.g., H7, H8). Table 6 reveals the mediation model testing outcomes. Mediation was examined based on an alpha of 0.05 . A test of mediation was conducted to determine whether grit mediated the relationship between self-confidence and self-efficacy. The direct effect between self-confidence and self-efficacy was significant, suggesting that full mediation by grit did not occur, although some partial mediation may still be present. Partial mediation was examined using the indirect and total effects of grit on the relationship between self-confidence and self-efficacy. Even if the total effect of self-confidence on self-efficacy was significant, $B=0.60, t=9.70$, $p<0.001$, indicating that a one-unit increase in self-confidence will increase the expected value of self-efficacy by 0.60 units, the indirect effect of grit on the relationship of selfefficacy regressed on self-confidence was non-significant, $\mathrm{B}=0.07, \mathrm{t}=1.43, p=0.154$, demonstrating that H7a was not supported. The direct effect between self-confidence and usefulness was not significant (see Figure 2), suggesting that full mediation by ease of use 
occurred. Thus, full mediation was examined using the indirect and total effects of ease of use on the relationship between self-confidence and usefulness. The indirect effect of ease of use on the relationship of usefulness regressed on self-confidence was significant, $B$ $=0.15, \mathrm{t}=2.39, p=0.018$. This result indicated that a one-unit increase in self-confidence, based on its effect on ease of use, will increase the expected value of usefulness by 0.15 units. The total effect of self-confidence on usefulness was significant, $B=0.20, t=2.51$, $p=0.012$, indicating that a one-unit increase in self-confidence will increase the expected value of usefulness by 0.20 units. Therefore, ease of use fully mediated the link between self-confidence and usefulness, supporting H8a.

Table 6. Specific indirect and total effects.

\begin{tabular}{|c|c|c|c|c|c|}
\hline & $\begin{array}{c}\text { Original } \\
\text { Sample }(O)\end{array}$ & $\begin{array}{c}\text { Sample } \\
\text { Mean (M) }\end{array}$ & $\begin{array}{c}\text { Standard Deviation } \\
\text { (STDEV) }\end{array}$ & $\begin{array}{l}\text { T Statistics } \\
\text { (|O/STDEVI) }\end{array}$ & $p$ Values \\
\hline Self-confidence -> Grit > Self-efficacy & 0.07 & 0.06 & 0.05 & 1.43 & 0.154 \\
\hline Self-confidence -> Ease of use $>$ Usefulness & 0.15 & 0.15 & 0.06 & 2.39 & 0.017 \\
\hline Ease of use $\rightarrow$ Usefulness & 0.80 & 0.80 & 0.05 & 17.81 & 0.000 \\
\hline Grit $\rightarrow$ Self-efficacy & -0.12 & -0.12 & 0.09 & 1.43 & 0.152 \\
\hline Self-confidence $\rightarrow$ Ease of use & 0.18 & 0.19 & 0.08 & 2.37 & 0.018 \\
\hline Self-confidence $\rightarrow$ Grit & -0.54 & -0.54 & 0.06 & 8.39 & 0.000 \\
\hline Self-confidence $\rightarrow$ Self-efficacy & 0.60 & 0.60 & 0.06 & 9.43 & 0.000 \\
\hline Self-confidence $\rightarrow$ Usefulness & 0.20 & 0.21 & 0.08 & 2.51 & 0.012 \\
\hline
\end{tabular}

Note: Relationships marked with yellow are statistically significant.

\section{Discussion}

\subsection{Theoretical Implications}

This study clarified the impact of self-confidence as the basic affective issue from which performance develops in 'grit' and behaviors related to lifelong learning strategies among Romanian employees during the COVID-19 pandemic (September 2020-March 2021). According to research hypotheses, the main outputs were that perceived selfconfidence has a significant direct effect on grit, on perceived self-efficacy, and on perceived ease of use of eLearning platforms for corporate training. In addition, perceived ease of use has a significant direct effect on the usefulness of eLearning platform usage. Moreover, this study demonstrated that the ease of use mediated the relationship between perceived self-confidence and usefulness of eLearning platform usage in corporate training during the COVID-19 pandemic. However, the following hypotheses were not confirmed:

Hypothesis 9 (H9). Perceived self-confidence does not have a significant direct effect on perceived usefulness.

Hypothesis 10 (H10). Grit does not have a significant direct effect on perceived self-efficacy.

Hypothesis 11 (H11). Grit does not act as a mediator in the relationship between perceived selfconfidence and self-efficacy of eLearning platform usage in corporate training during the COVID-19 pandemic.

Note: " $\mathrm{b}$ " represent negative Hypothesis

Previous studies highlighted that self-confidence as a physiological state is important in decision-making effectiveness [78]. Therefore, self-confidence can be a predictor of self-efficacy. However, researchers have rarely described the impact of perceived selfconfidence on grit, ease of use, and usefulness of virtual training of workers. Present results show that self-confidence management is considered essential for the company success that means efficiency [79], similar to other studies [80]. The explanation is that one critical component of leadership is confidence perceived as behaviors in familiar and unfamiliar circumstances [81] such as lifelong learning situations [82]. Additionally, this study also 
reinforced the significant role of self-confidence as a predictor of grit in terms of consistency of interest [83].

Self-confidence in relation to self-efficacy plays an important role in successful participation through educational activities [84-87]. These results are similar to those obtained in this study. Adults prefer activities in which they feel comfortable and in which they successfully complete any task [88]. Hugh [89] discussed individual effectiveness in the context of task efficiency. In spite of task complexity, the company will progress, considering that there is a close relationship between self-confidence and self-efficacy. However, the present findings do not support the influence of 'grit' in predicting self-efficacy as performance of employees. This outcome differs from the results of university students [83] but is similar to the results of college students. In this research, self-confidence has a total effect on the perceived usefulness of an eLearning platform, a predictor of intention to use the digital educational tool. Consequently, this research result supports indirectly the research result of Daragmeh et al. [87], which states that self-confidence has a significant influence on digital tool adoption. Hence, the current study provides support that strengthening employees' self-confidence produces double benefits: promoting usefulness of eLearning platforms in corporate training and increasing the self-efficacy in workplaces.

\subsection{Managerial Implications}

Currently, an increasing number of companies have decided to acquire and use learning management systems, but the degree of adoption is still low. This evidence creates the question of the motivation for the use of technology in the training of workers. Establishing and exploring factors contributing to the perceived job context in terms of beliefs and efficiency, in the particular context of adult learning, were the main aims of this research.

Researchers have found that grit significantly predict career preparation behavior, but only in some particular case [90]. Also, past research has supported the hypothesis that a learner's performance is associated with grit in terms of perseverance of effort [91]. The lack of significant results for predicting self-efficacy by grit is intriguing but similar to other studies [82]. The effect on grit might be evident in longer-term studies. When looking at the capacity to predict usefulness by self-confidence, no direct effect was observed. However, the ease of use is a powerful predictor of utility perception.

Additionally, a significant overall self-confidence effect on usefulness was observed. This finding is consistent with previous research $[63,92,93]$. Perceived ease of use is the major determinant of perceived usefulness, suggesting that ease of use is a key factor in accepting the use of a particular digital tool. Wolters and Hussain [94] investigated and compared involvement focus on different aspects of grit. They demonstrated that the consistency of interest, as a facet of grit, was associated only with students' self-regulated learning. Moreover, previous findings found that both perseverance and consistency were important in predicting psychological results [62]. However, Datu et al. showed that perseverance of effort was more relevant in predicting key psychological outcomes contrasted to the consistency of interest [95]. Interestingly, the current study confirmed that consistency of interest has no impact on self-efficacy as a psychological response across employees in a virtual training context. This finding indicates arguments for managers to investigate mainly the perseverance of effort as an effect of grit in relation to career success. Additionally, increasing the perception of the utility of technology will enhance the motivation of employees to learn from eLearning [96], thus contributing to improved performance at the workplace. If the employees perceived the training courses as easier to navigate through them, perceived usefulness is assured. This solution is how the learner's motivation will remain at a satisfactory level. The results of this research show a strong correlation between the perception of the usefulness of eLearning platforms and ease of use in workplace training. Consequently, the company managers will have to take these psychological aspects into account to increase work efficiency. Briefly, the implication of this research to the management is that managers must pay special attention 
to training employees using eLearning platforms that have intuitive and easy-to-navigate functionalities. In addition, managers should ensure that eLearning tools are proper for the users' profiles.

\section{Limitations and Future Lines of Research}

In this study, an adapted questionnaire that measures self-confidence, grit, usefulness, ease of use, and self-efficacy was validated among 307 employees. However, the survey was difficult to conduct during the COVID-19 pandemic because of employees' fears that they might be laid off based on their responses. Therefore, a large number of responses ( $n=93$ ) are missing, and consequently, a significant number of items were eliminated during the model adjustments. In this context, a revalidation investigation is necessary for a different sample of employees. In the future, a more varied and larger sample to capture the employees' profiles is recommended. In addition, during the measurement model validation, a low cut-off value of 0.5 for item factor loading was set, which generated four items with poor quality. For the future, setting a higher cut-off value of 0.7 for item factor loading will ensure that only good items will be included in the research. Another limitation of this study is that the intention to use eLearning platforms was not considered. To compare more deeply our own results with those of other studies, other latent variables (e.g., different grit dimensions, attitude toward eLearning, intention to use digital tools, etc.) will be considered in the future.

\section{Conclusions}

The importance of lifelong education for developing human capital is unanimously recognized. Digitization, which facilitates access to educational resources, plays an important role in lifelong learning. Understanding and improving personal skills can contribute to success at the workplace. During the pandemic, the entire population was affected. Distance and restrictive practices have disrupted traditional educational practices, and people have had to embrace online learning. Nowadays, the most unconvinced but also the supporters of eLearning strategies have directed their attention to learning from assisted technology. In this context, studies investigating the relationships between cognitive and non-cognitive factors that possibly influence the efficiency of work are useful.

The topic addressed in this research is a challenging subject in this context affected by the COVID-19 pandemic. The links between non-cognitive and cognitive outcomes such as job performance in terms of self-efficacy and acceptance of digital tools are extensively investigated. This study extends traditional models by studying the impact of a single noncognitive factor (e.g., self-confidence) on two distinct response variables (e.g., self-efficacy and usefulness of eLearning in corporate training). Hence, the main goal of this research was to investigate the relationships of some individual non-cognitive (e.g., self-confidence, grit, and self-efficacy) and cognitive factors (e.g., ease of use and usefulness). The research outcomes will provide empirical support for lifelong learning solutions.

This research assumes a quantitative approach of employee beliefs regarding online corporate training using eLearning platforms that advances our understanding related to work performance predictors. Consequently, the novelty of this research is given by identifying factors that can increase performance in work by increasing work efficiency and perception of corporate training usefulness.

The outputs of this research are based on an analysis of experimental data from 307 employees from Romania. In this context, five major findings of this research can be summarized. First, an employee's self-confidence was directly and positively related to the consistency of interest as a grit dimension and to self-efficacy. Building and maintaining self-confidence offer a context in which employees can consolidate the capability to remain focused and enthusiastic for a long time while completing a specific task. Second, a direct effect of an employee's self-confidence on self-efficacy of eLearning platforms was demonstrated. Therefore, self-confidence plays a key role in effective online learning at the workplace. Third, a direct effect of an employee's self-confidence on perceived ease 
of use of eLearning platforms and a total effect of self-confidence on perceived usefulness mediated by the ease of use were observed. This finding reveals that perceived ease of use of eLearning platforms will be enhanced by increasing self-confidence. This study also provided evidence that perceived usefulness can be influenced by self-confidence, and ease of use plays a mediation role between these variables. Fourth, ease of use as a TAM dimension is an important predictor of perceived usefulness. Fifth, consistency of interest as a grit dimension was not related to employee self-efficiency. This finding demonstrates that consistency of interest is irrelevant to efficacy of online learning in corporate training. However, maintaining the motivation of learners for constant work perfection is a challenge for the future. In other words, self-sufficiency and lack of desire for lifelong learning must be prevented. In addition, a constant adaptation of the objectives, content, and methods of eLearning is necessary for the realities of contemporary society. The continuous improvements of employees' competencies are the solution that makes a competitive company in the market. Knowledge management is considered essential for the success of a company. Ease of use of digital tools increases users' perceived benefit of eTraining. However, educational setting requirements such as work environment should not be neglected at all. Definitely, the COVID-19 pandemic influences the corporate training contexts.

These results reinforce the conviction that both cognitive and non-cognitive factors have an obvious predictive role in workplace performance despite being frequently unpredictable. Therefore, a permanent evaluation of cognitive and non-cognitive factors in different lifelong learning contexts is recommended to improve work motivation and indirectly work performance. Thus, to promote lifelong learning effectively through a virtual environment, company trainers should use eLearning platforms and develop their strategies corresponding to different psychological contexts. The findings can help managers proactively design efficient training strategies. In addition, a radical change in the paradigm of the lifelong learning concept and in turn the switch to new forms of eLearning and more attention to adult education should be taken into consideration by companies. It is the base of a high-level quality of national human capital that contributes to a sustainable society.

Supplementary Materials: The initial data base is available online at https://www.mdpi.com/ article/10.3390/su13126633/s1, Table S1: Data set for explore the relationship between self-confidence, self-efficacy, grit, usefulness, and ease of use eLearning platforms in corporate training during the Covid-19 pandemic in Romania.

Author Contributions: Conceptualization, A.M., and I.L.; methodology, A.M., G.P., and I.L.; validation: I.L., and G.P. supervision, G.P., and I.L.; writing —original draft preparation, A.M., G.P., and I.L.; writing-review and editing, A.M., G.P., and I.L. All authors have read and agreed to the published version of the manuscript.

Funding: This research received no external funding.

Institutional Review Board Statement: The study was conducted according to the guidelines of the Declaration of Helsinki.

Informed Consent Statement: The completion of the questionnaire by the volunteer participants confirmed that the informed consent was obtained from all subjects involved in the study. This research is part of an extended project that aims to investigate the behavior of various educational actors towards online education.

Data Availability Statement: Not applicable.

Acknowledgments: The authors would like to thank the participants who were involved in the present research.

Conflicts of Interest: The authors declare no conflict of interest. 


\section{References}

1. Torres Martín, C.; Acal, C.; El Homrani, M.; Mingorance Estrada, Á.C. Impact on the Virtual Learning Environment Due to COVID-19. Sustainability 2021, 13, 582. [CrossRef]

2. Peñarrubia-Lozano, C.; Segura-Berges, M.; Lizalde-Gil, M.; Bustamante, J.C. A Qualitative Analysis of Implementing E-Learning during the COVID-19 Lockdown. Sustainability 2021, 13, 3317. [CrossRef]

3. Panisoara, I.O.; Lazar, I.; Panisoara, G.; Chirca, R.; Ursu, A.S. Motivation and Continuance Intention towards Online Instruction among Teachers during the COVID-19 Pandemic: The Mediating Effect of Burnout and Technostress. Int. J. Environ. Res. Public Health 2020, 17, 8002. [CrossRef] [PubMed]

4. Malureanu, C.; Malureanu, A.; Lazar, G. Motivational Factors of the Usage of Web 2.0 Tools for E-Learning in Business. In Handbook of Research on User Experience in Web 2.0 Technologies and Its Impact on Universities and Businesses; Jean-Éric, P., Ed.; IGI Global: Hershey, PA, USA, 2021; pp. 231-249.

5. Xu, S.; Zhang, M.; Hou, L. Formulating a learner model for evaluating construction workers' learning ability during safety training. Saf. Sci. 2019, 116, 97-107. [CrossRef]

6. Lee, Y.J.; Lee, D. Factors Influencing Learning Satisfaction of Migrant Workers in Korea with E-learning-Based Occupational Safety and Health Education. Saf. Health Work 2015, 6, 211-217. [CrossRef]

7. Mo, C.-Y.; Hsieh, T.-H.; Lin, C.-L.; Jin, Y.Q.; Su, Y.-S. Exploring the Critical Factors, the Online Learning Continuance Usage during COVID-19 Pandemic. Sustainability 2021, 13, 5471. [CrossRef]

8. Batalla-Busquets, J.-M.; Martínez-Argüelles, M.-J. Determining factors in online training in companies. Int. J. Manag. Educ. 2014, 12, 68-79. [CrossRef]

9. Alhadabi, A.; Karpinski, A.C. Grit, self-efficacy, achievement orientation goals, and academic performance in University students. Int. J. Adolesc. Youth 2020, 25, 519-535. [CrossRef]

10. Quezada, R.; Rivera, L.; Delgadillo, R.; Cajo, B.H. Technological Aspects for Pleasant Learning: A Review of the Literature. Informatics 2021, 8, 25. [CrossRef]

11. Yoon, C.; Choi, B. Role of Situational Dependence in the Use of Self-Service Technology. Sustainability 2020, 12, 4653. [CrossRef]

12. Liu, C.; He, J.; Ding, C.; Fan, X.; Hwang, G.-J.; Zhang, Y. Self-oriented learning perfectionism and English learning burnout among EFL learners using mobile applications: The mediating roles of English learning anxiety and grit. Learn. Individ. Differ. 2021, 88, 102011. [CrossRef]

13. Sturman, E.D.; Zappala-Piemme, K. Development of the grit scale for children and adults and its relation to student efficacy, test anxiety, and academic performance. Learn. Individ. Differ. 2017, 59, 1-10. [CrossRef]

14. Pagani, M. Determinants of adoption of third generation mobile multimedia services. J. Interact. Mark. 2004, 18, 46-59. [CrossRef]

15. Kalita, G. Analyzing the Level of Self Confidence of the Post Graduate Students in Relation to Certain Variables. Psychol. Educ. J. 2021, 58, 1381-1383.

16. Bandura, A. Self-Efficacy. In The Corsini Encyclopedia of Psychology; Weiner, I.B., Craighead, W.E., Eds.; John Wiley \& Sons: Hoboken, NJ, USA, 2010; pp. 1-3.

17. Bandura, A.; Freeman, W.; Lightsey, R. Self-efficacy: The exercise of control. J. Cogn. Psychother. 1999, 13, 158-166. [CrossRef]

18. White, K.A. Self-confidence: A concept analysis. In Nursing Forum; Blackwell Publishing Inc.: Malden, MA, USA, 2009; pp. 103-114.

19. Nokelainen, P.; Tirri, K.; Merenti-Välimäki, H.-L. Investigating the influence of attribution styles on the development of mathematical talent. Gift. Child Q. 2007, 51, 64-81. [CrossRef]

20. Plecha, M. The Impact of Motivation, Student-Peer, and Student-Faculty Interaction on Academic Self-Confidence. Available online: https: / files.eric.ed.gov/fulltext/ED464149.pdf (accessed on 21 May 2021).

21. Oleson, K.C.; Poehlmann, K.M.; Yost, J.H.; Lynch, M.E.; Arkin, R.M. Subjective overachievement: Individual differences in self-doubt and concern with performance. J. Personal. 2000, 68, 491-524. [CrossRef] [PubMed]

22. Savitsky, K.; Medvec, V.H.; Charlton, A.E.; Gilovich, T. “What, me worry?" Arousal, misattribution, and the effect of temporal distance on confidence. Personal. Soc. Psychol. Bull. 1998, 24, 529-536. [CrossRef]

23. Hilgenkamp, K.D.; Livingston, M.M. Tomboys, masculine characteristics, and self-ratings of confidence in career success. Psychol. Rep. 2002, 90, 743-749. [CrossRef] [PubMed]

24. Kumar, S.; Jagacinski, C.M. Imposters have goals too: The imposter phenomenon and its relationship to achievement goal theory. Personal. Individ. Differ. 2006, 40, 147-157. [CrossRef]

25. Harris, S.L. The Relationship between Self-Esteem and Academic Success among African American Students in the Minority Engineering Program at a Research Extensive University in the Southern Portion of the United States. Ph.D. Thesis, Louisiana State University and Agricultural and Mechanical College, Baton Rouge, LA, USA, 2009.

26. Al-Hebaish, S.M. The correlation between general self-confidence and academic achievement in the oral presentation course. Theory Pract. Lang. Stud. 2012, 2, 60-65. [CrossRef]

27. Pierce, J.L.; Gardner, D.G.; Cummings, L.L.; Dunham, R.B. Organization-based self-esteem: Construct definition, measurement, and validation. Acad. Manag. J. 1989, 32, 622-648.

28. Dörnyei, Z. The Psychology of the Language Learner: Individual Differences in Second Language Acquisition; Routledge: New York, NY, USA, 2014. 
29. De Cremer, D.; Van Knippenberg, D. Leader self-sacrifice and leadership effectiveness: The moderating role of leader selfconfidence. Organ. Behav. Hum. Decis. Process. 2004, 95, 140-155. [CrossRef]

30. Ozuorcun, N.C.; Tabak, F. Is m-learning versus e-learning or are they supporting each other? Procedia Soc. Behav. Sci. 2012, 46, 299-305. [CrossRef]

31. Clarke, A. The future of e-learning. Adults Learn. 2007, 18, 14-15.

32. Zwart, D.P.; Noroozi, O.; Van Luit, J.E.; Goei, S.L.; Nieuwenhuis, A. Effects of Digital Learning Materials on nursing students' mathematics learning, self-efficacy, and task value in vocational education. Nurse Educ. Pract. 2020, 44, 102755. [CrossRef]

33. Schunk, D.H. Self-efficacy and academic motivation. Educ. Psychol. 1991, 26, 207-231. [CrossRef]

34. Panisoara, G. Psihologia Invatarii. Cum Invata Copiii si Adultii? Polirom: Iasi, Romania, 2019.

35. Garaika, G.; Margahana, H.M.; Negara, S.T. Self Efficacy, Self Personality and Self Confidence on Entrepreneurial Intention: Study on Young Enterprises. J. Entrep. Educ. 2019, 22, 1-12.

36. Gist, M.E.; Mitchell, T.R. Self-efficacy: A theoretical analysis of its determinants and malleability. Acad. Manag. Rev. 1992, 17, 183-211. [CrossRef]

37. Alqurashi, E. Self-efficacy in online learning environments: A literature review. Contemp. Issues Educ. Res. (CIER) 2016, 9, 45-52. [CrossRef]

38. Hodges, C.B. Self-efficacy in the context of online learning environments: A review of the literature and directions for research. Perform. Improv. Q. 2008, 20, 7-25. [CrossRef]

39. Artino, A.R. Motivational beliefs and perceptions of instructional quality: Predicting satisfaction with online training. J. Comput. Assist. Learn. 2008, 24, 260-270. [CrossRef]

40. Hodges, C. Self-efficacy, Motivational Email, and Achievement in an Asynchronous Math Course. J. Comput. Math. Sci. Teach. 2008, 27, 265-285.

41. Joo, Y.J.; Lim, K.Y.; Kim, J. Locus of control, self-efficacy, and task value as predictors of learning outcome in an online university context. Comput. Educ. 2013, 62, 149-158. [CrossRef]

42. Joo, Y.-J.; Bong, M.; Choi, H.-J. Self-efficacy for self-regulated learning, academic self-efficacy, and internet self-efficacy in web-based instruction. Educ. Technol. Res. Dev. 2000, 48, 5-17. [CrossRef]

43. Lin, Y.-M.; Lin, G.-Y.; Laffey, J.M. Building a Social and Motivational Framework for Understanding Satisfaction in Online Learning. J. Educ. Comput. Res. 2008, 38, 1-27. [CrossRef]

44. Shea, P.; Bidjerano, T. Learning presence: Towards a theory of self-efficacy, self-regulation, and the development of a communities of inquiry in online and blended learning environments. Comput. Educ. 2010, 55, 1721-1731. [CrossRef]

45. Xiao, J. Successful and unsuccessful distance language learners: An 'affective' perspective. Open Learn. J. Open Distance e-Learn. 2012, 27, 121-136. [CrossRef]

46. Gebara, N.L. General Self-Efficacy and Course Satisfaction in Online Learning: A Correlational Study. Ph.D. Thesis, University of Missouri, Columbia, MO, USA, 2010.

47. Peechapol, C.; Na-Songkhla, J.; Sujiva, S.; Luangsodsai, A. An Exploration of Factors Influencing Self-Efficacy in Online Learning: A Systematic Review. Int. J. Emerg. Technol. Learn. 2018, 13, 64-86. [CrossRef]

48. Bates, R.; Khasawneh, S. Self-efficacy and college students' perceptions and use of online learning systems. Comput. Hum. Behav. 2007, 23, 175-191. [CrossRef]

49. Duckworth, A.L.; Peterson, C.; Matthews, M.D.; Kelly, D.R. Grit: Perseverance and passion for long-term goals. J. Personal. Soc. Psychol. 2007, 92, 1087. [CrossRef]

50. Aparicio, M.; Bacao, F.; Oliveira, T. Grit in the path to e-learning success. Comput. Hum. Behav. 2017, 66, 388-399. [CrossRef]

51. Duckworth, A.; Gross, J.J. Self-control and grit: Related but separable determinants of success. Curr. Dir. Psychol. Sci. 2014, 23, 319-325. [CrossRef] [PubMed]

52. Duckworth, A. Grit: The Power of Passion and Perseverance Hardcover; Scribner: New York, NY, USA, 2016.

53. Tang, X.; Wang, M.-T.; Guo, J.; Salmela-Aro, K. Building grit: The longitudinal pathways between mindset, commitment, grit, and academic outcomes. J. Youth Adolesc. 2019, 48, 850-863. [CrossRef]

54. Hill, P.L.; Jackson, J.J. The invest-and-accrue model of conscientiousness. Rev. Gen. Psychol. 2016, 20, 141-154. [CrossRef]

55. Totosy de Zepetnek, J.O.; Martin, J.; Cortes, N.; Caswell, S.; Boolani, A. Influence of grit on lifestyle factors during the COVID-19 pandemic in a sample of adults in the United States. Personal. Individ. Differ. 2021, 175, 110705. [CrossRef] [PubMed]

56. Davis, F.D.; Bagozzi, R.P.; Warshaw, P.R. Extrinsic and Intrinsic Motivation to Use Computers in the Workplace1. J. Appl. Soc. Psychol. 1992, 22, 1111-1132. [CrossRef]

57. Ajzen, I. The theory of planned behavior. Organ. Behav. Hum. Decis. Process. 1991, 50, 179-211. [CrossRef]

58. Scherera, R.; Siddiq, F.; Tondeur, J. The technology acceptance model (TAM): A meta-analytic structural equation modeling approach to explaining teachers' adoption of digital technology in education. Comput. Educ. 2019, 128, 13-35. [CrossRef]

59. Lazar, I.; Panisoara, G.; Panisoara, I.-O. Adoption of digital storytelling tool in natural sciences and technology education by pre-service teachers using the technology acceptance model. J. Balt. Sci. Educ. 2020, 19. [CrossRef]

60. Iliescu, D.; Popa, M.; Dimache, R. Adaptarea românească a Setului International de Itemi de Personalitate: IPIP-Ro [The Romanian adaptation of the International Personality Item Pool: IPIP-Ro]. Psihol. Resur. Um. 2015, 13, 83-112.

61. Edwards, S.J. Research participation and the right to withdraw. Bioethics 2005, 19, 112-130. [CrossRef] [PubMed] 
62. Duckworth, A.L.; Quinn, P.D. Development and validation of the Short Grit Scale (GRIT-S). J. Personal. Assess. 2009, 91, 166-174. [CrossRef] [PubMed]

63. Lazar, I.M.; Panisoara, G.; Panisoara, I.O. Digital technology adoption scale in the blended learning context in higher education: Development, validation and testing of a specific tool. PLOS ONE 2020, 15, e0235957. [CrossRef]

64. Intellectus, S. Online Computer Software. Available online: https:/ /analyze.intellectusstatistics.com/ (accessed on 21 May 2021).

65. Field, A. Discovering Statistics Using IBM SPSS Statistics, 4th ed.; Sage Publications: Thousand Oaks, CA, USA, 2017.

66. Shieh, G. Optimal sample sizes for the design of reliability studies: Power consideration. Behav. Res. Methods 2014, 46, 772-785. [CrossRef] [PubMed]

67. Osborne, J.; Costello, A.B. Sample size and subject to item ratio in principal components analysis. Prac. Assess. Res. Eval. 2004, 9 11.

68. Ogbeibu, S.; Emelifeonwu, J.; Senadjki, A.; Gaskin, J.; Kaivo-oja, J. Technological turbulence and greening of team creativity, product innovation, and human resource management: Implications for sustainability. J. Clean. Prod. 2020, 244, 118703. [CrossRef]

69. Wang, F.H. On the relationships between behaviors and achievement in technology-mediated flipped classrooms: A two-phase online behavioral PLS-SEM model. Comput. Educ. 2019, 142, 103653. [CrossRef]

70. Boubker, O.; Douayri, K. Dataset on the relationship between consumer satisfaction, brand attitude, brand preference and purchase intentions of dairy product: The case of the Laayoune-Sakia El Hamra region in Morocco. Data Brief 2020, $32,106172$. [CrossRef]

71. Tintner, G. Multicollinearity. Appl. Math. Comput. 1975, 1, 233-242. [CrossRef]

72. Smith, K.W.; Sasaki, M.S. Decreasing Multicollinearity: A Method for Models with Multiplicative Functions. Sociol. Methods Res. 1979, 8, 35-56. [CrossRef]

73. Hair, J.; Hult, G.T.M.; Ringle, C.; Sarstedt, M. A Primer on Partial Least Squares Structural Equation Modeling (PLS-SEM), 2nd ed.; SAGE Publications, Inc.: Thousand Oaks, CA, USA, 2016.

74. Qasem Ali, A.; Md Sultan, A.B.; Abd Ghani, A.A.; Zulzalil, H. An Empirical Investigation of Software Customization and Its Impact on the Quality of Software as a Service: Perspectives from Software Professionals. Appl. Sci. 2021, 11, 1677. [CrossRef]

75. Acosta-Prado, J.C.; López-Montoya, O.H.; Sanchís-Pedregosa, C.; Vázquez-Martínez, U.J. Sustainable Orientation of Management Capability and Innovative Performance: The Mediating Effect of Knowledge Management. Sustainability 2020, 12, 1366. [CrossRef]

76. Henseler, J.; Ringle, C.M.; Sarstedt, M. A new criterion for assessing discriminant validity in variance-based structural equation modeling. J. Acad. Mark. Sci. 2015, 43, 115-135. [CrossRef]

77. Greenland, S.; Senn, S.J.; Rothman, K.J.; Carlin, J.B.; Poole, C.; Goodman, S.N.; Altman, D.G. Statistical tests, P values, confidence intervals, and power: A guide to misinterpretations. Eur. J. Epidemiol. 2016, 31, 337-350. [CrossRef]

78. Hallo, L.; Nguyen, T.; Gorod, A.; Tran, P. Effectiveness of Leadership Decision-Making in Complex Systems. Systems 2020, 8, 5. [CrossRef]

79. Martelo-Landroguez, S.; Cepeda-Carrión, G. How knowledge management processes can create and capture value for firms? Knowl. Manag. Res. Pract. 2016, 14, 423-433. [CrossRef]

80. Axelrod, R.H. Leadership and Self-Confidence. In Leadership Today: Practices for Personal and Professional Performance; Marques, J., Dhiman, S., Eds.; Springer: Berlin/Heidelberg, Germany, 2017.

81. Oney, E.; Oksuzoglu-Guven, G. Confidence: A Critical Review of the Literature and an Alternative Perspective for General and Specific Self-Confidence. Psychol. Rep. 2015, 116, 149-163. [CrossRef]

82. Weisskirch, R.S. Grit, Self-Esteem, Learning Strategies and Attitudes and Estimated and Achieved Course Grades among College Students. Curr. Psychol. 2018, 37, 21-27. [CrossRef]

83. Ferradás, M.d.M.; Freire, C.; Núñez, J.C.; Regueiro, B. The Relationship between Self-Esteem and Achievement Goals in University Students: The Mediating and Moderating Role of Defensive Pessimism. Sustainability 2020, 12, 7531. [CrossRef]

84. Hammer, M.; Scheiter, K.; Stürmer, K. New technology, new role of parents: How parents' beliefs and behavior affect students' digital media self-efficacy. Comput. Hum. Behav. 2021, 116, 106642. [CrossRef]

85. Jokisch, M.R.; Schmidt, L.I.; Doh, M.; Marquard, M.; Wahl, H.-W. The role of internet self-efficacy, innovativeness and technology avoidance in breadth of internet use: Comparing older technology experts and non-experts. Comput. Hum. Behav. 2020, 111, 106408. [CrossRef]

86. Muhonen, H.; Pakarinen, E.; Rasku-Puttonen, H.; Lerkkanen, M.-K. Educational dialogue among teachers experiencing different levels of self-efficacy. Learn. Cult. Soc. Interact. 2021, 29, 100493. [CrossRef]

87. Daragmeh, A.; Sági, J.; Zéman, Z. Continuous Intention to Use E-Wallet in the Context of the COVID-19 Pandemic: Integrating the Health Belief Model (HBM) and Technology Continuous Theory (TCT). J. Open Innov. Technol. Mark. Complex. 2021, 7, 132. [CrossRef]

88. Porter, K.; Smith, P.; Fagg, R. Chapter 3-Leadership and motivation at work. In Leadership and Management; Porter, K., Smith, P., Fagg, R., Eds.; Butterworth-Heinemann: Oxford, UK, 2006; pp. 65-97.

89. Hugh, J. Chapter 5-People and teams. In Engineering Design, Planning, and Management, 2nd ed.; Jack, H., Ed.; Academic Press: Cambridge, MA, USA, 2021; pp. 149-209.

90. Lee, S.; Sohn, Y. Effects of grit on academic achievement and career-related attitudes of college students in Korea. Soc. Behav. Personal. An Int. J. 2017, 45, 1629-1642. [CrossRef] 
91. Bowman, N.A.; Hill, P.L.; Denson, N.; Bronkema, R. Keep on Truckin' or Stay the Course? Exploring Grit Dimensions as Differential Predictors of Educational Achievement, Satisfaction, and Intentions. Soc. Psychol. Personal. Sci. 2015, 6, 639-645. [CrossRef]

92. Punnoose, A. Determinants of Intention to Use eLearning Based on the Technology Acceptance Model. J. Inf. Technol. Educ. Res. 2012, 11, 301-337. [CrossRef]

93. Chao, C.-M. Factors Determining the Behavioral Intention to Use Mobile Learning: An Application and Extension of the UTAUT Model. Front. Psychol. 2019, 10. [CrossRef]

94. Wolters, C.; Hussain, M. Investigating grit and its relations with college students' self-regulated learning and academic achievement. Metacogn. Learn. 2015, 10. [CrossRef]

95. Datu, J.A.D.; Valdez, J.P.M.; King, R.B. Perseverance Counts but Consistency Does Not! Validating the Short Grit Scale in a Collectivist Setting. Curr. Psychol. 2016, 35, 121-130. [CrossRef]

96. Mehta, A.; Morris, N.P.; Swinnerton, B.; Homer, M. The Influence of Values on E-learning Adoption. Comput. Educ. 2019, 141, 103617. [CrossRef] 